\title{
An Archival Testament: the Papers of Sir William Dawson
}

\author{
By Robert H. Michel \\ Project Archivist, Canadian Centre for Architecture
}

\section{A Biography at Last}

Coinciding fortunately with McGill's celebration of its 175th year, McGill-Queen's University Press has published the first, full scale, scholarly biography of Sir William Dawson (1820-1899), McGill's chief architect and Principal from 1855 to 1893: John William Dawson: Faith, Hope and Science by Professor Susan Sheets-Pyenson. Historians of McGill, Stanley Frost and Margaret Gillett and historians of science such as Suzanne Zeller, Charles O'Brien and many others have described Dawson's critical role in the development of McGill, geology, museums, and scientific networks but Sheets-Pyenson's book is the first since the publication of Dawson's autobiography in 1901 to bring us back to the man himself--Canada's eminent Victorian, driven as her subtitle suggests by "faith, hope and science." Dawson combined several careers into one: scientist, religious controversialist, University Principal, advocate of Protestant English education in Quebec, and tireless paterfamilias as well. Sheets-Pyenson offers a thorough, inspired, scientific and personal biography of the Principal who built McGill up from the little college with a Medical Faculty he found in 1855 to Canada's premier university by the time he retired in 1893 . She portrays a researcher forced to become an administrator who performed both functions well but never achieved quite what he wanted-especially the reconciliation of Scripture with geology and palaeontology.

The author draws attention to how much her biography depends on archives-from bills and scribbles to letters from other scientists, pointing out that while Dawson's thought may be studied through his publications, knowledge of the man himself depends on the thousands of letters and writings he and his wife and children carefully preserved. She declares that the richness of Dawson's archive allowed her to expand her originally-intended scientific biography into a full one covering personal and family life. Confirming to some extent the theories of biography advanced by Leon Edel and others, she notes that biographers bring their own lives and concerns to bear on their accounts of their subjects' lives; she observes that she became more interested in Dawson's family and economic concerns as she herself changed and brought up her children over the decade she worked on the book. While she occasionally speculates as to Dawson's motives (though never wildly), she mainly holds to the hard core of Victorian facts. ${ }^{\prime}$

This fine biography also provides an occasion to examine how personal papers advance knowledge. Unlike institutional records, private papers need not be kept permanently for legal or administrative reasons. Yet they can become their creator's intellectual testament and contribution to the future. ${ }^{2}$ By preserving his papers Dawson made his biography possible. And the preservation of the papers of Dawson's wife and children lets us study Dawson and other family members in greater depth and in relation to one another.

\section{Constant Writer and Record Keeper}

Dawson carefully kept his papers for the future, arranged them, and mounted some of them in albums intended for his own reference and his family's enjoyment and edification. They contain such things as his letter of appointment to McGill, wedding memorabilia, and sketches of the Nova Scotia countryside where he grew up. He probably referred back to his papers and albums when writing his autobiography. At first one is surprised that this introspective Victorian did not keep a diary to take stock of his life and to record events. It seems likely that he simply did not have the time. Always busy, he published several hundred articles and nearly two dozen books; he preferred to devote his writing energy to getting into print. 

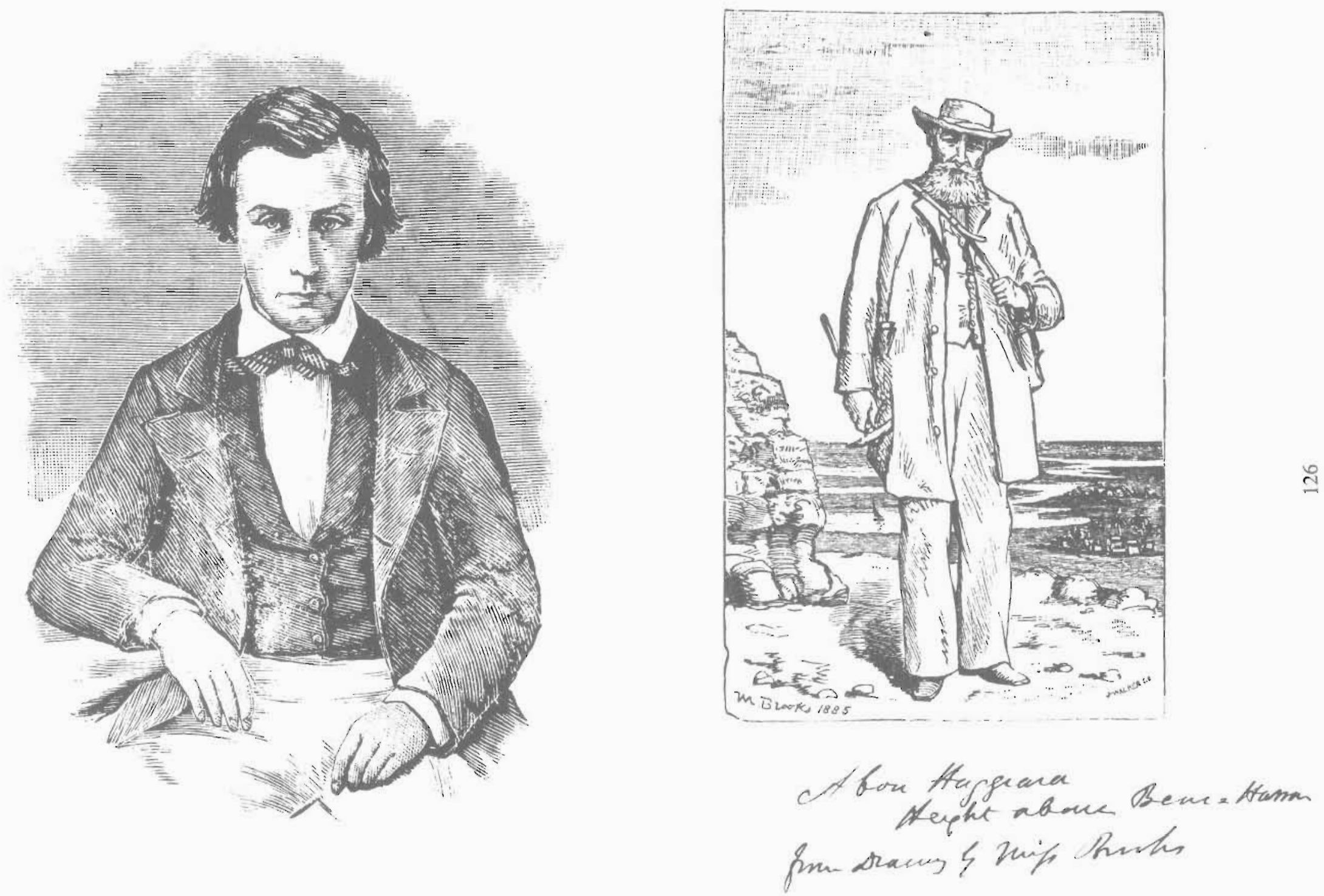

Figure 1. J.W. Dawson, from Daguerrotype, c. 1846. (J.W. Dawson's album of drawings. McGill University Archives)

Figure 2. J.W. Dawson, pencil sketch by Miss Brooks, 1885. Verso annotated: "To the father of stones with compliments of $\mathrm{M}$ Brooks." (McGill University Archives) 
Dawson's papers reveal that, whatever his activity, he was an obsessive note taker. He wrote quickly and. illegibly, often in pocket sized booklets; he made sketches of specimens, strata, Egyptian. antiquities and fossils (some developed by engravers into illustrations for his books). He scribbled and kept for reference firsts drafts or: copies of correspondence-he was his own camera and xerox machine. He was always writing, according to his grand-daughter, Clare Harrington. ${ }^{3}$

The immense amount of writing that Dawson did helped him keep his busy life and innumerable projects under: control. His surviving papers are a witness to his concern for details and effective "time management." His daughter Anna remembered how he kept lists of things to be done:

He always was an early riser, usually downstairs by 7 [o'clock] \&. doing a great deal of his daily correspondence before 8 [o'clock] breakfast... he was very systematic \& regular in his habits \& never seemed to put off anything. It was the secret of his never neglecting little things, that he always attended to them at once.... He always kept a memo book \& every engagement was noted. in it that he had. if this book was missing it was a calamity, and we all flew to assist in the search for it. ${ }^{4}$

\section{The Autobiography}

Dawson wrote his autobiography (perhaps long planned) in the last years of his life. Published as Fifty Years of Work in Canada (1901), it was his tally of achievements and failures; a summing up. The Dawson archive exemplifies how the accumulation of private papers (less compulsory than the creation and keeping of institutional records) gains a new life and purpose as a research source. While most people save their letters and bills for their own reference, with no larger purpose in mind, one suspects that Dawson with his faith in the progress of discoverable knowledge knew his letters and scientific and educational notes (like his publications) would have value in the future--for his own autobiography perhaps and for his family and others. He may have had the same motive for keeping his papers as for writing his autobiography:

It has been truly said, that the story of any human being, has its lessons either of encouragement or of warning. I make no apology therefore for preparing the sketches that follow,-more especially as many of them refer to persons and events of much more importance than what pertains to myself individually.... They, will, in any case, I trust, be of some interest to my children and grandehildren, and perhaps to others who may have been influenced by my teaching. ${ }^{5}$

It is surprising that after Dawson died in 1899 no biography appeared, except in obituaries. Dawson had completed his autobiography, however. Though it contained moving phrases about his life here and there, it lacked drama and failed to convey Dawson's great achievements. Much of it bogged down into detail about research and congresses or quoted previously published addresses. Lady Dawson, and the children Anna, George and Rankine wrangled for months over what use to make of the autobiography and whether it would be preferable to publish instead a biography by a historian; they mentioned McGill Professor Charles Colby as a possibility. Finally, Rankine, opposed by George, fulfilled his father's charge to look after the autobiography and published it in $1901 .{ }^{6}$

\section{The Archival Stage}

Sir William Dawson's private papers (including papers of other family members such as geologist George Mercer Dawson and son-in-law Bernard Harrington) came to McGill in two major phases: the Harrington children gave a large collection of Dawson's scientific and family correspondence to the McGill Library in the 1.920s and. Lois Winslow-Spragge, a grand-daughter, gave the McGill University Archives more of Dawson's and other family 
papers in the 1960s and 1970s. The concern of the Dawson and Harrington families for preserving their papers and making them available to scholars at McGill has shaped the way we see nineteenth-century Canadian science. Concurrent with the boom in Canadian history in the 1970s and 1980s, the papers were heavily consulted for a multitude of projects --to cite just two: Suzanne Zeller's Inventing Canada and Cynthia Fish's doctoral thesis on Montreal fatherhood. ${ }^{7}$ Judging by their usage, the Dawson Papers are probably McGill's most important holding of unpublished private papers-certainly the most important for Canadian scientific history. ${ }^{8}$

From about 1970 to the mid-1980s, the McGill Archives described and indexed Dawson's papers against a background of rapidly changing descriptive standards and technology. As well the papers, which originally came in dozens of accessions, were physically arranged into a unified archival fonds. The McGill Department of Rare Books and Special Collections cooperated in the effort to describe the papers globally and make them available at one site by turning its Dawson papers over to the Archives. In a series of projects, the 1970s multilith item-level listings of isolated groups of letters were superseded in the 1980 s by computer-assisted indexes to virtually all the Dawson family papers. ${ }^{9}$ Though earlier finding aids became outdated, each generation of them helped guide researchers to what they needed in the ten linear metres of Dawson's papers.

\section{Undiscovered Dawson}

Dawson's written testament started early in his life, in his native Pictou, Nova Scotia. Except for Stanley Frost's article on Dawson's courtship letters to his future wife Margaret Mercer, his youthful writing, before 184.5, has rarely been examined. ${ }^{10}$ Dawson studied at renowned Pictou Academy, spent a year at Edinburgh and then ran his father's book and stationary business. His writings at this time reflect his reading and his study of the rocks, wild life and flora around Pictou. The seed of all that would follow is evident in the papers that survive from this period. Dawson collected and wrote compulsively from the age of fifteen or so; the Archives contain notes and essays which he may have done while a student at Pictou Academy, or perhaps served as the basis of lectures to the Pictou Literary Society and to Pictou Academy in his late teens and twenties. By 1836, when he was sixteen, Dawson's handwriting had sped to illegibility. He probably kept his early essays for their continuing usefulness and may have recycled some for lectures and teaching in Montreal. Subjects included: snow crystals (with folded paper geometric examples); caterpillars; moths and spiders; Indian antiquities; "speculations on the limits of science"; "Notes on Some of the Birds of Nova Scotia"; "Zoological Changes Produced by Cultivation"; linguistics; entomology; and local coal mining. He had the awe of nature found in romantic landscapes of the time. He absorbed advanced ideas on the preservation of the earth's ecology. Although he became in many ways a scientific and social conservative in his later years, the young Dawson of Pictou had a creative concern for nature that was as poetic as it was scientific. In an essay on "The Forest" (perhaps aged 16, ca. 1836?), referring to the clearing of Nova Scotia for farming and timber sales, he wrote about the land as a living thing, threatened far more by man than by natural catastrophes:

The wild chaos of barren rocks and mountains, shining in the summer's sun, or wreathed with the clouds and battered with the storms of winter, ... display nature in her sterner forms, grandly but terribly.....Such and more is the forest but man the great spoiler of nature's beauty...wars against the woods. The noble trees the growth of centuries, are destined to fali before the puny arms of a being that seems but a reptile, at their feet. And faster and more surely do they rush to destruction before the desolating fire that, his carelessness creates and his feeble efforts cannot arrest-flames that hiss and crackle as they curl around the lofty trees that seem to writhe in agony beneath them, and rush insatiably forward converting luxuriant beauty into the blackness of desolation and leaving the bare scathed trunks stretching their gnarled and blasted branches to the sky-the ruins of the forest. ${ }^{11}$ 
Dawson's early writing was relatively free of reference to scripture; his love of nature became all the more formidable once fortified by his rather fundamentalist religion. At all ages, he investigated everything that interested him, took notes and kept them, for publication or contemplation. He wrote his modest autobiography as his last work and in the fullness of time received, in Sheets-Pyenson, the biographer he may have hoped for. Shown here are two drawings which convey the long journey that his papers document-one of the thin young man, about to marry at twenty-six and run a book store in Pictou (1846); the other as Canada's premier scientist and university Principal, aged sixty-five (1885), worrying that he was losing his battle against Darwinism and Catholic obscuranticism but proud of his publications, his family, and his university, McGill. As the University takes stock of itself after 175 years, it can be proud of its guardianship of these and many other records of Canada's heritage, given to it in trust, for the advancement of learning.

\section{Notes}

1. Susan Sheets-Pyenson, John William Dawson: Faith, Hope, and Science, McGill-Queen's University Press, Montreal, 1996, pp. 9-11. 2. Dawson's administrative records as Principal (as opposed to his private papers) were found by University Archivist John Andreassen in the late 1960s, in the Arts Building, in tin boxes, folded up into bundles. Part of the official administrative records of McGill, they reveal Dawson's involvement in every level of University administration. Like Dawson's private papers, these records have been extensively mined: by Stanley Frost and Margaret Gillett and their assistants for histories of McGill, and by hundreds of others, including McGill students studying the history of Montreal institutions under Prof. Brian Young.

3. Sheets-Pyenson, John William Dawson, p. 11.

4. Anna Dawson Harrington, biographical notes on Sir William Dawson (probably prepared to assist George or Rankine Dawson, ca. 1900, pp. 4-5. McGill University Archives, Dawson Papers, MG 1022, C 64 (punctuation and cross-outs edited).

5. John William Dawson, Fifty Years of Work in Canada, London, 1901, vii-viii.

6. See Sheets-Pyenson, John William Dawson, pp. 207-211. The published autobiography, as Sheets-Pyenson notes, differs from the incomplete MSS draft in the McGill Archives (Dawson Papers, MG 1022, C 22). The extent to which Rankine rephrased it is unclear.

7. Suzanne Zeller, Inventing Canada, Toronto, 1987; Cynthia Fish, "Images and Reality of Fatherhood: a Case Study of Montreal's Protestant Middle Class 1870-1914", Ph.D., McGill, 1991.

8. When I applied in 1974 for a job as archivist in the McGill Archives, I had just returned from doing research in England on marriage in the seventeenth century for my (eventual) McGill Ph.D. The then University Archivist, John Andreassen, blew cigar smoke at me and growled: "Why does the History Department send a guy like you to England when we have something like the Dawson Papers right here in McGill's Archives?" He was at the high point of collecting and issuing near-print listings of Dawson's letters as Principal, as well as some of the family and scientific correspondence, and could not understand how historians could pass them by in favour of the overworked archives and thesis topics of Europe. He need not have worried; the study of Canadian history was surging forward and by the mid-1970s, Dawson's papers began to be used extensively.

9. In the $1980 \mathrm{~s}$, the McGill Archives produced an in-house computer-assisted author/recipient/date index to its holdings of the scientific and family correspondence and papers of J.W. Dawson and various family members (R. Craig, editor). In the later 1970s, a computer-assisted index to Dawson's records as Principal (with subject fields) was produced with the help of Stanley Frost's History of McGill Project (L. Vardi and J. King, editors). Published in 1992 was Susan Sheets-Pyenson, ed., Index to the Scientific Correspondence of John William Dawson (BSHS Monograph 7), British Society for the History of Science, 1992; while this index does not cover Dawson's correspondence with family and the papers of other family members, it includes J.W. Dawson letters held outside McGill.

10. Stanley Frost, "A Transatlantic Wooing," Dalhousie Review 58 (1978), pp. 458-470.

11. "The Forest", Dawson Papers, MG 1022, C 25, folder 3. 